\title{
SOME NUTRITIONAL AND ANTI-NUTRITIONAL FACTORS OF ZP SOYA BEAN VARIETIES
}

\section{Vesna D. Dragičević ", Vesna A. Perić, Mirjana B. Srebrić, Slađana M. Žilić and Snežana D. Mladenović Drinić}

\author{
Maize Research Institute "Zemun Polje”, Slobodana Bajića 1, \\ 11085 Belgrade-Zemun, Serbia
}

\begin{abstract}
The nutritive quality of soya bean grain depends on many nutritional and anti-nutritional factors, such as proteins, trypsin inhibitors, phytate, phenolics, sulfhydril groups of proteins, malondialdehide. The aim of this study was to investigate content of noted nutritive and anti-nutritive factors in seven ZP soya bean varieties: ZPS 015, Bosa, Nena, Lidija, Olga, Lana and Laura. Experimental data could point out different properties and usage of ZP soya bean varieties. Regardless of insignificant differences in content of proteins and phytate, special attention is given to Lana and Laura, varieties lacking in Kunitz-trypsin inhibitor. It is also important to emphasise high content of phenolics in Nena variety as well as high sulfhydril groups and glutathione level in Nena and Olga. These substances contribute to nutritive value of soya bean grain.
\end{abstract}

Key words: soya bean grain, nutritional quality, anti-nutrients.

\section{Introduction}

The nutritional quality of soya bean grain depends on many factors. Mature soya bean grain contains a number of anti-nutritional components with various level of biological activity. The most important among them are protease inhibitors. Their presence prohibits the utilisation of raw soya bean as food and feed and requires heat treatment in order to become fully inactivated (Perić et al., 2009). The improvements in decreasing or eliminating trypsin inhibitors lead to enhancement of nutritional quality. The other important anti-nutrient present in soya bean grain is phytate. It is not digested by monogastric animals, so it does not provide monogastrics with sufficient phosphorus and minerals and it leads to phosphorus runoff causing $\mathrm{P}$ pollution of ground water from animal wastes (Bilyeu et al., 2008).

*Corresponding author: e-mail: vdragicevic@mrizp.sr 
Meanwhile, soya bean grain contains proteins with sulfhydril groups which play a very important role as antioxidants. Beside their role in trapping of free radicals and prevention of stress (Chernikova et al., 2000; Santos and Rey, 2006) they could reduce trypsin inhibitors, such as Kunitz-trypsin inhibitor (Kobrehel et al., 1991). Malenčić et al. (2007) are emphasising phenolics, as main contributors of antioxidative activity in soya bean grain. Genotypes poor in phenolics also showed low level of antioxidative activity. The results suggested that the content of phenolics should be considered as an important and specific attribute of soya bean grain and as a potential selection criterion for antioxidant activity in soya bean. The oxidative activity in soya bean results in production of many co- and products which have anti-nutritive effects, like malondialdehyde (MDA), the product of lipid peroxidation. MDA is mutagenic in human cells (Niedernhofer et al., 2003) and it could also react with free amino groups in proteins and DNA bases (Štajner et al., 1993).

The aim of the study was to investigate content of anti-nutritive factors, such as trypsin inhibitors, phytate and malondialdehyde as well as valuable nutritive factors: crude and soluble proteins, inorganic phosphorus, phenolics, total sulfhydril groups and glutathione in seven ZP soya bean varieties.

\section{Materials and Methods}

The four-replicate trial was set up in the experimental field of the Maize Research Institute in Zemun Polje on a slightly calcareous chernozem type of soil under irrigation during 2009. The standard cultivation practice was applied. Soya bean grain of seven genotypes: ZPS 015, Bosa, Nena, Lidija, Olga, Lana and Laura were analysed to determine content of some structural components, antioxidants and products of lipid peroxidation.

Structural components consider crude and soluble proteins, determined by modified methods of Allen (1931) and Lowry et al. (1951). The content of trypsin inhibitors (TI) was estimated according to a modified Erlanger method (Hamerstrand et al., 1981). Total phosphorus was determined after wet digestion with $\mathrm{HNO}_{3}+\mathrm{HClO}_{4}$ by method of Pollman (1991). Inorganic phosphorus $\left(\mathrm{P}_{\mathrm{i}}\right)$ and phytic phosphorus $\left(\mathrm{P}_{\text {phy }}\right)$ were analysed from 5\% TCA extract by method of Pollman (1991) - $\mathrm{P}_{\mathrm{i}}$ and method of Jočić (1996) - $\mathrm{P}_{\text {phy. The antioxidants were }}$ analysed: total phenolics by method of Simić et al. (2004), total thiolic groups (PSH) by method of de Kok et al. (1981) and total glutathione (GSH) by method of Sari Gorla et al. (1993). The product of lipid peroxidatin, malondialdehyde (MDA) was analysed by method of Stewart and Bewley (1980).

The experimental data were statistically processed by the analysis of variance (ANOVA) and analysed by the LSD test. 


\section{Results and Discussion}

The highest content of crude and soluble proteins was determined in Nena. As it was expected, the significantly lowest content of trypsin inhibitors was present in Lana and Laura (for 54\% and 65\%, respectively, compared to other varieties), the varieties lacking in Kunitz-trypsin inhibitor. The slightly lower TI content, found in Nena and Olga varieties, could be due to the activity of thioredoxines (PSH), of which content is the highest in these varieties (Table 2). The results of Kobrehel et al. (1991) confirm that thioredoxins, including reduced form of GSH reduce TI in soya bean grain.

The content of phenolics varied significantly among varieties. ZPS 015 and Bosa had the lowest content of phenolics (for $31 \%$ and $28 \%$, respectively) compared to other varieties. The highest content of phenolics was determined in Nena and Lidija. It was interesting to underline that relative high content of phenolics (Table 1) and MDA (Table 2) as well as low PSH content in Lidija grain could point at a low potential for protein trapping of free radicals, which could emphasise the activity of phenolics in observed variety, confirmed by Malenčić et al. (2007), too.

Table 1. The content of seed moisture, crude protein, soluble proteins, trypsin inhibitors and phenolics in grain of seven ZP soya bean varieties.

\begin{tabular}{lcccc}
\hline \multirow{2}{*}{ Variety } & \multicolumn{3}{c}{ Proteins $\left(\mathrm{mg} \mathrm{g}^{-1}\right)$} & $\begin{array}{c}\text { Phenolics } \\
\left(\mathrm{mg} \mathrm{g}^{-1}\right)\end{array}$ \\
\cline { 2 - 4 } & Crude & Soluble & TI & 522.95 \\
ZP 015 & 369.38 & 263.96 & 32.39 & 542.70 \\
Bosa & 386.25 & 286.13 & 34.01 & 805.63 \\
Lidija & 390.63 & 303.28 & 30.80 & 792.26 \\
Olga & 359.38 & 291.51 & 32.01 & 660.72 \\
Lana & 376.88 & 293.50 & 30.36 & 760.73 \\
Laura & 363.75 & 300.22 & 14.62 & 758.45 \\
\hline Average & 373.13 & 292.27 & 11.20 & 691.92 \\
\hline LSD 0.05 & 374.20 & 290.12 & 26.48 & 95.88 \\
\hline
\end{tabular}

The majority of phosphorus content in soya bean grain is stored in phytate (Bilyeu et al. 2008), so as the content of total $\mathrm{P}$ and $\mathrm{P}_{\text {phy }}$ did not vary significantly among the examined varieties (Table 2). The phosphorus, trapped in form of $\mathrm{P}_{\mathrm{i}}$ during grain filling, which is extremely digestible (Bilyeu et al. 2008) had the highest values in Lana, while the significantly lowest value was in Olga.

The importance of sulfhydril groups as an anti-stress factor is well known (Chernikova et al., 2000). Among examined varieties, Nena and Olga expressed the 
highest PSH content (Table 2), which with high GSH content, found in Olga underlined it as variety with possibly high anti-oxidative potential, based on thioredoxins (Santos and Rey, 2006). On the other hand, low PSH and GSH content in the grain of Lidija, could point at low thioredoxin activity in trapping of free radicals.

Table 2. The content of total phosphorus, inorganic and phytic phosphorus, total thiolic groups, total glutathione and malondialdehyde in a grain of seven ZP soya bean varieties.

\begin{tabular}{|c|c|c|c|c|c|c|}
\hline \multirow{2}{*}{ Variety } & \multicolumn{3}{|c|}{ Phosphorus ( $\left.\mathrm{mg} \mathrm{g}^{-1}\right)$} & \multicolumn{2}{|c|}{ Thiolics $\left(\mathrm{nmol} \mathrm{g}^{-1}\right)$} & \multirow{2}{*}{$\begin{array}{c}\text { MDA } \\
\left(\mathrm{nmol} \mathrm{g}^{-1}\right)\end{array}$} \\
\hline & Total & $\mathrm{P}_{\mathrm{i}}$ & $\mathrm{P}_{\text {phy }}$ & PSH & GSH & \\
\hline ZP 015 & 2.98 & 0.26 & 2.30 & 108.54 & 69.61 & 41.18 \\
\hline Bosa & 2.72 & 0.23 & 1.49 & 229.16 & 83.05 & 17.55 \\
\hline Nena & 3.02 & 0.23 & 2.24 & 372.73 & 82.08 & 41.18 \\
\hline Lidija & 2.57 & 0.26 & 1.88 & 151.49 & 69.96 & 91.96 \\
\hline Olga & 2.80 & 0.15 & 1.97 & 374.97 & 119.02 & 82.60 \\
\hline Lana & 2.82 & 0.31 & 1.95 & 265.83 & 78.61 & 95.71 \\
\hline Laura & 3.02 & 0.24 & 2.28 & 104.99 & 43.03 & 55.93 \\
\hline Average & 2.85 & 0.24 & 2.02 & 229.67 & 77.91 & 60.87 \\
\hline LSD $0.05^{*}$ & 0.94 & 0.09 & 0.98 & 84.87 & 7.91 & 25.66 \\
\hline
\end{tabular}

The significantly high MDA content in Lidija, Olga and Lana could indicate a high oxidative activity. It was also important to underline that observed varieties were rich in antioxidants: Lidija in phenolics, while Olga and Lana had the highest content of GSH and PSH, respectively. Nena, as a variety with the highest protein content (crude and soluble, Table 1) as well as $\mathrm{P}_{\text {phy }}$ (Table 2), had the lowest MDA content, what could potentially suggest that phytate in soya bean grain plays a protective role-against reactions with products of lipid peroxidation (Štajner et al., 1993).

\section{Conclusion}

Based on the data obtained in this research, it could be concluded that the level of examined nutritional and anti-nutritional factors could determine properties and usage of ZP soya bean varieties. Special attention is given to Lana and Laura, varieties lacking in Kunitz-trypsin inhibitor. But it is also important to emphasise a high content of phenolics, as main antioxidant present in soya bean grain in Nena as well as high PSH and GSH level in Nena and Olga. 


\section{Acknowledgements}

This research was supported by the Ministry of Science and Technology, the Republic of Serbia, Project TR 20114.

\section{References}

Allen, W.F. (1931): A micro-Kjeldahl method for nitrogen determination. J. Am. Oil Chem. Soc. 8:391-397.

Bilyeu, K.D., Zeng, P., Coello, P., Zhang, Z.J., Krishnan, H.B., Bailey, A., Beuselinck, P.R., Polacco, J.C. (2008): Quantitative conversion of phytate to inorganic phosphorus in soybean seeds expressing a bacterial phytase. Plant Physiol. 146:468-477.

Chernikova, T., Robinson, J.M., Lee, E.H., Mulchi, C.L. (2000): Ozone tolerance and antioxidant enzyme activity in soybean cultivars. Photosynth. Res. 64:15-26.

De Kok, L.J., de Kan, P.J.L., Tanczos, G., Kupier, J.C. (1981): Sulphate induced accumulation of glutathione and frost-tolerance of spinach leaf tissue. Physiol. Plant. 53:435-438.

Hamerstrand, G.E., Black, L.T., Glover, J.D. (1981): Trypsin inhibitors in soy products: modification of the standard analytical procedure. Cereal Chem. 58:42-45.

Jočić, N. (1996): Ispitivanje sadržaja rastvorljivog fitina u semenu hibrida kukuruza $F_{1}$ generacije u fazi mirovanja. Specijalistički rad, Hemijski fakultet, Beograd.

Kobrehel, K.S., Yee, B.C., Buchanans, B.B. (1991): Role of the NADP/thioredoxin system in the reduction of a-amylase and trypsin inhibitor proteins. JBC 266(24):16135-16140.

Lowry, O.H., Rosebrough, N.J., Farr, A.L., Randall, R.J. (1951): Protein measurement with the Folinphenol reagent. JBC 193:265-275.

Malenčić, Đ., Popović, M., Miladinović, J. (2007): Phenolic content and antioxidant properties of soybean (Glycine max (L.) Merr.) seeds. Molecules 12(3):576-581.

Niedernhofer, L.J., Daniels, J.S., Rouzer, C.A., Greene, R.E., Marnett, L.J. (2003): Malondialdehyde, a product of lipid peroxidation, is mutagenic in human cells. JBC 278(33):31426-31433.

Perić, V., Srebrić, M., Jankuloski, Lj., Jankuloska, M., Žilić, S., Kandić, V., Drinić-Mladenović, S. (2009): The effects of nitrogen on protein and trypsin inhibitor content of soybean. Genetika 41(2):137-143.

Pollman, R.M. (1991): Atomic absorption spectrophotometric determination of calcium and magnesium and colorimetric determination of phosphorus in cheese: collaborative study. J. Assoc. Anal. Chem. 74:27-31.

Santos, C.V.D., Rey, P. (2006): Plant thioredoxins are key actors in the oxidative stress response. Trends Plant Sci. 11(7):329-334.

Sari-Gorla, M., Ferrario, S., Rossini, L., Frova, C., Villa, M. (1993): Developmental expression of glutathione-S-transferase in maize and its possible connection with herbicide tolerance. Euphytica 67(3):221-230.

Simić, A., Sredojević, S., Todorović, M., Đukanović, L., Radenović, Č. (2004): Studies on the relationship between content of total phenolics in exudates and germination ability of maize seed during accelerated aging. Seed Sci. Technol. 32:213-218.

Stewart, R.R.C., Bewley, J.D. (1980): Lipid peroxidation associated aging of soybean axes. Plant Physiology 65:245-248.

Štajer, D., Gašić, O., Matkovics, B., Kraljević-Balalić, M., Varga, S.I. (1993): Lipid peroxidation and reduced glutathione in wheat seeds and their $\mathrm{F}_{1}$ hybrids. Cereal. Res. Commun. 21:181-185.

Received: March 30, 2010

Accepted: July 27, 2010 


\title{
NEKI NUTRITIVNI I ANTINUTRITIVNI FAKTORI ZP SORTI SOJE
}

\section{Vesna D. Dragičević*, Vesna A. Perić, Mirjana B. Srebrić, Slađana M. Žilić i Snežana D. Mladenović Drinić}

\author{
Institut za kukuruz “Zemun Polje”, Slobodana Bajića 1, \\ 11085 Beograd-Zemun, Srbija \\ R e z i m e
}

Nutritivni kvalitet zrna soje zavisi od sadržaja brojnih nutrienata i antinutrienata, kao što su proteini, tripsin inhibitori, fitat, fenoli, sulfhidrilne grupe proteina i malondialdehid. Cilj istraživanja je bio da se ispita sadržaj navedenih nutritivnih i antinutritivnih faktora u zrnu sedam ZP sorti soje: ZP 015, Bosi, Neni, Lidiji, Olgi, Lani i Lauri. Eksperimentalni rezultati ukazuju različite mogućnosti korišćenja ZP sorti soje. Bez obzira na to što su razlike u sadržaju proteina i fitata beznačajne, posebna pažnja je data Lani i Lauri kao sortama koje nemaju Kunitztrypsin inhibitor. Takođe je važno istaći visok sadžaj fenola u zrnu sorte Nena, kao i visok nivo PSH i GSH kod sorata Nena i Olga, što doprinosi njihovoj većoj nutritivnoj vrednosti.

Ključne reči: zrno soje, nutritivna vrednost, antinutrienti.

Primljeno: 30. marta 2010.

Odobreno: 27. jula 2010.

*Autor za kontakt: e-mail: vdragicevic@mrizp.sr 